\title{
Múltiples abscesos en un cerdo causados por Trueperella pyogenes (Arcanobacterium pyogenes): Reporte de caso
}

\author{
Multiple abscesses in a pig caused by Trueperella \\ pyogenes (Arcanobacterium pyogenes): Case report
}

\author{
Noel Verjan Garcíaa, Geiner Alberto Almario Leivaa, Néstor Jaime Romero Jolaa, \\ Luz Clemencia Fandiñoa
}

\begin{abstract}
RESUMEN
Un Cerdo Duroc Jersey de dos años de edad y $250 \mathrm{~kg}$ de peso presentó una masa de consistencia dura en el pliegue cutáneo del cuello, e inflamación severa de la articulación del tarso del miembro posterior derecho. El cultivo microbiológico del contenido identificó la bacteria Gram-positiva Trueperella (Arcanobacterium) pyogenes, la cual fue sensible a varios antibióticos incluidos la gentamicina y sulfa-trimetoprim. Los abscesos se drenaron y el cerdo se trató con sulfa-trimethoprim a dosis de $20 \mathrm{mg} / \mathbf{k g}$ por cinco días, y posteriormente con gentamicina a dosis de $5 \mathrm{mg} / \mathrm{kg}$ por cinco días en asociación con antínflamatorios. Los abscesos reemergieron, el cerdo se sacrificó y se realizó la necropsia. El aislamiento de $T$. pyogenes a partir de artritis supurativa y abscesos cutáneos en un cerdo indica la necesidad de implementar vigilancia epidemiológica y métodos de diagnóstico rápido en la industria porcina del departamento del Tolima.
\end{abstract}

PALABRAS CLAVE: Cerdos, Abscesos, Lesiones cutáneas, Duroc-Jersey, Trueperella pyogenes.

\begin{abstract}
A two-year-old male Duroc Jersey pig with $250 \mathrm{~kg}$ body-weight presented a swollen mass tissue of hard consistency in the ventral side of the neck skin fold and severe inflammation at the tarsal joint of the right hind limb. The Gram-positive bacteria Trueperella (Arcanobacterium) pyogenes was isolated in pure culture by microbiological methods and was sensitive to several antibiotics including Gentamicin and Sulfa-trimethoprim. The abscesses were drained and the pig treated with sulfa-trimethoprim at $20 \mathrm{mg} / \mathrm{kg}$ for $5 \mathrm{~d}$ and later with gentamicin at $5 \mathrm{mg} / \mathrm{kg}$ for $5 \mathrm{~d}$ together with anti-inflammatory drugs. The abscesses re-emerged and the pig was sacrificed and the anatomo-pathological findings at necropsy recorded. $T$. pyogenes caused severe suppurative arthritis and cutaneous abscesses in a pig, suggesting the need of surveillance and rapid diagnostics methods in the Tolima pig industry.
\end{abstract}

KEY WORDS: Swine, Abscesses, Skin lesions, Duroc-Jersey, Trueperella pyogenes.

Trueperella (Arcanobacterium pyogenes) es una bacteria Gram-positiva y comensal que causa infecciones oportunistas después de trauma físico(1). T. pyogenes es un bacilo corto no móvil, no forma esporas y forman pequeñas colonias blancas capaces de crecer en
Trueperella (Arcanobacterium) pyogenes is a Gram-positive and commensal bacterium that cause opportunistic infections upon physical trauma(1). T. pyogenes is non-motile, non-spore forming short bacillus that form white small colonies able to grow under both aerobic and

Recibido el 24 de febrero de 2014. Aceptado el 24 de julio de 2014.

a Grupo de Investigación Inmunobiología y Patogénesis, Facultad de Medicina Veterinaria y Zootecnia, Universidad del Tolima. Santa Helena Parte Alta, Ibagué, Colombia. AA. 546. nverjang@ut.edu.co. 
condiciones aerobias como anaerobias estrictas(2). La bacteria tiene un metabolismo estrictamente fermentativo, no produce indol, ureasa o catalasa pero produce amplias zonas de $\beta$-hemólisis en agar sangre. T. pyogenes fue inicialmente nombrado Corynebacterium pyogenes, después Actinomyces pyogenes y subsecuentemente Arcanobacterium pyogenes(3). Recientemente, análisis filogenético basado en secuencias del gen 16S rRNA, composición de fosfolípidos y menaquinona permitió su clasificación como Trueperella pyogenes( 4 ).

T. pyogenes normalmente habita en las superficies epiteliales y mucosas de los animales domésticos, incluyendo la mucosa gástrica(5). Se ha aislado a partir de lesiones supurativas que involucran la piel, las articulaciones, la ubre y el tracto urogenital en bovinos, ovinos, cabras y cerdos $(2,4)$. Las lesiones comunes son cutánea(6), hepática(7) y abscesos renales(8). Sin embargo, $T$. pyogenes también causa mastitis y endometritis $(9,10)$. Los abscesos en las canales de cerdo son debidos principalmente a métodos de inyección inapropiados, falta de desinfección o el uso común de la aguja y jeringas(11). Los abscesos causados por $T$. pyogenes, solos o en combinación con otros agentes han sido la principal causa del desecho de canales al sacrificio $(12,13)$. Sin embargo, el impacto económico de esta infección es desconocida.

Aunque rara vez documentado, T. pyogenes causa abscesos subcutáneos en humanos(14), que pueden progresar a enfermedad sistémica(15). Así, la presencia de T. pyogenes en las canales de cerdos constituye un riesgo para su transmisión al humano. Este reporte describe el desarrollo de múltiples abscesos causados por T. pyogenes en un cerdo criado en la región de Tolima, Colombia.

\section{Examen del paciente}

Anamnesis. Un cerdo macho de dos años de edad de raza Duroc-Jersey con $250 \mathrm{~kg}$ de peso corporal e historia clínica donde se registra una strictly anaerobic conditions(2). The bacterium has a metabolism strictly fermentative, does not produce indole, urease or catalase but produces wide zones of $\beta$-hemolysis in blood agar. $T$. pyogenes was initially named Corynebacterium pyogenes, later Actinomyces pyogenes and subsequently Arcanobacterium pyogenes(3). Recently, phylogenetic analysis based on the 16S rRNA gene sequences, menaquinone and phospholipid composition allowed the classification as Trueperella pyogenes( 4 ).

T. pyogenes normally inhabits the epithelial and mucosal surfaces of domestic animals, including the gastric mucosa(5). It has been isolated from suppurative lesions involving the skin, joints, udder and urogenital tract in bovine, ovine, goats and swine $(2,4)$. The common lesions are cutaneous $(6)$, hepatic $(7)$ and kidney abscesses $(8)$. However, T. pyogenes also causes mastitis and endometritis $(9,10)$. Abscesses in pork carcasses are due to inappropriate injection methods, lack of disinfection or common use of needle and syringes(11). Abscesses caused by T. pyogenes alone or in combination with other agents have been the main cause of carcasses condemnation at slaughter(12,13), however, the economic impact of this infection is unknown.

Although rarely reported, T. pyogenes causes subcutaneous abscesses in humans(14), that may progress into systemic disease(15). Thus, the presence of $T$. pyogenes in pig's carcasses may constitute a risk for its transmission to human. This report describes the development of multiple abscesses caused by $T$. pyogenes in a pig reared in the Tolima region, Colombia.

\section{Patient's examination}

Anamnesis: A two-year-old male Duroc Jersey pig with $250 \mathrm{~kg}$ body-weight and history of a spherical and swollen mass of tissue of hard consistency in the neck skin fold was examined by veterinarian practitioners. The vital signs were within the normal range and the mass was punctured with a fine needle. Abundant pus 
masa esférica de tejido de consistencia dura en el pliegue de la piel del cuello, fue examinado por médicos veterinarios. Los signos vitales estuvieron dentro del rango normal y la masa se drenó con una aguja fina. Se colectó abundante pus y se envió para cultivo microbiológico al Laboratorio de Diagnostico Veterinario de la Universidad del Tolima. También se llevó a cabo una resección quirúrgica del absceso. El cerdo se trató con enrofloxacina a dosis de $5 \mathrm{mg} / \mathrm{kg}$ cada $24 \mathrm{~h}$ durante 7 días, y flunixina meglumina a dosis de $2.2 \mathrm{mg} / \mathrm{kg}$ cada 24 h durante 3 días; limpieza y desinfección con una solución de yodo comercial.

Hallazgos clínicos. Cuatro meses después de la resección del absceso, el cerdo mostró disminución del apetito, reaparición del absceso del pliegue cutáneo del cuello y nuevos abscesos en la articulación del tarso de la extremidad posterior derecha (Figura $1 \mathrm{~A}, \mathrm{~B}$ ). El cerdo había perdido peso y la condición corporal fue muy pobre. Al examen físico se encontró una frecuencia cardiaca de 94 , la respiración 64 , la temperatura rectal de $39.7^{\circ} \mathrm{C}$, tiempo de llenado capilar de $1 \mathrm{seg}$, pulso simétrico y fuerte, las was collected and a sample was sent to the Laboratory of Veterinary Diagnosis (LVD) at the University of Tolima for microbiological culture. Surgical resection of the abscess was also performed. The pig was treated with Enrofloxacin at $5 \mathrm{mg} / \mathrm{kg}$ every $24 \mathrm{~h}$ for $7 \mathrm{~d}$, Flunixin meglumine at $2.2 \mathrm{mg} / \mathrm{kg}$ every $24 \mathrm{~h}$ for $3 \mathrm{~d}$, and daily cleaning and disinfection with a commercial iodine solution.

Clinical findings: Four months later the pig showed reduced appetite, re-emergence of the neck skin fold abscess and novel abscesses at the tarsal joint of the right hind limb (Figure 1 A, B). The pig had reduced body-weight and poor body condition. Physical examination found a heart rate 94 , respiration 64 , rectal temperature $39.7^{\circ} \mathrm{C}$, capillary refill time $1 \mathrm{sec}$, symmetrical and strong pulse, reddened mucous membranes and abdominal breathing pattern.

\section{Treatment}

The pig was isolated and the abscesses were drained (Figure 1C) and about $500 \mathrm{~mL}$ of pus were collected, a second sample of pus was submitted for microbiological culture. Sulfa-

Figura 1. Múltiples abscesos cutáneos causados por Trueperella pyogenes, en un cerdo DurocJersey

Figure 1. Multiple cutaneous abscesses caused by Trueperella pyogenes in a Duroc-Jersey pig

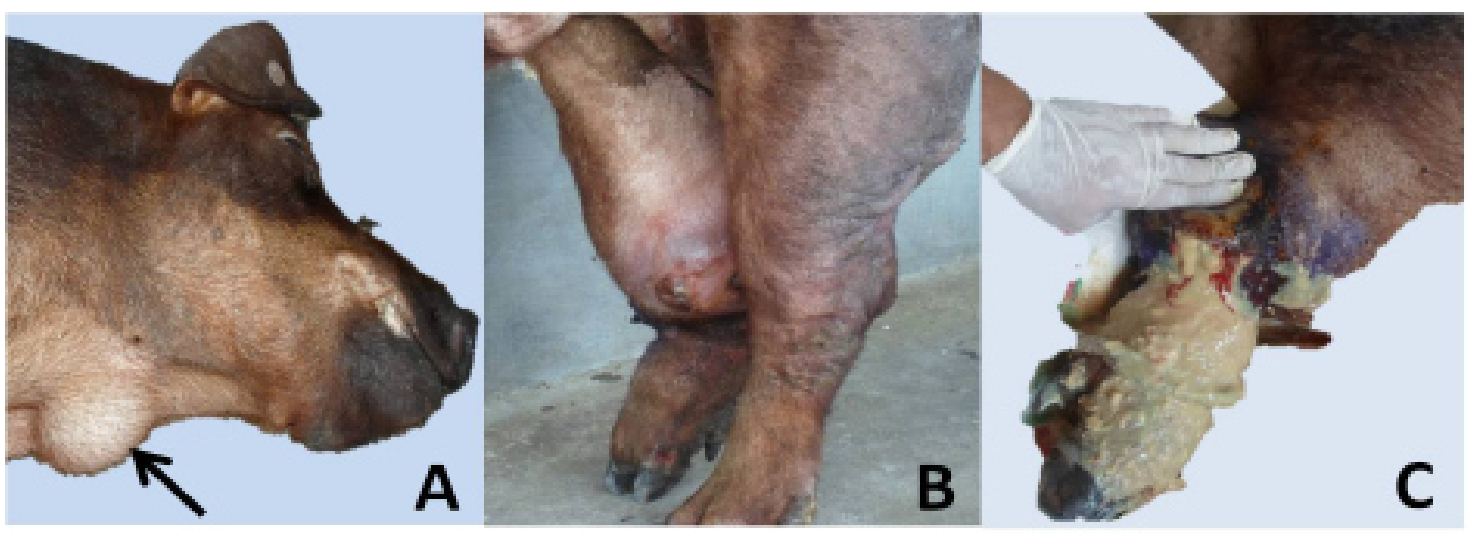

A) An abscess located at the neck skinfold that had previously been drained has re-emerged (Arrow).

B. Severe suppurative inflammation of the tarsal joint of the right hind limb due to multiple abscesses.

C). Drainage of the abscesses showed a collection of about $500 \mathrm{~mL}$ of pus that emerged from the lesions. 
mucosas enrojecidas y patrón de respiración abdominal.

\section{Tratamiento}

El cerdo fue aislado y los abscesos se drenaron (Figura $1 \mathrm{C}$ ); se recogieron alrededor de 500 $\mathrm{ml}$ de pus, del cual una segunda muestra se sometió a cultivo microbiológico. La terapia de sulfa-trimetoprim se inició a una dosis de 20 $\mathrm{mg} / \mathrm{kg}$ durante cinco días junto con flunixina meglumina. El cerdo recuperó el apetito dos días más tarde y un mes más tarde el apetito se redujo de nuevo y el cerdo mostró fiebre e inflamación severa en la extremidad posterior derecha. El cerdo se sometió a una segunda cirugía con extirpación de la cápsula de absceso y el tejido necrótico, un tapón de gasa apretada impregnada con antibióticos se colocó dentro de la herida. Terapia con gentamicina se inició a una dosis de $5 \mathrm{mg} / \mathrm{kg}$ y ketoprofeno a $3 \mathrm{mg} /$ $\mathrm{kg}$. El cerdo recuperó parcialmente el consumo de alimento y el movimiento, pero tenía muy mala condición física; se sacrificó con Euthanex ® (Invet, Bogotá, Colombia) por vía intravenosa, seguido de un examen de necropsia. trimethoprim therapy was started at a dose of $20 \mathrm{mg} / \mathrm{kg}$ for $5 \mathrm{~d}$ along with Flunixin meglumine. The pig recovered the appetite two days later and one month later the appetite dropped again and the pig showed fever and severe inflammation in the right hind limb. The pig underwent a second surgery with removal of the abscess's capsule and necrotic tissue and a tight gauze tampon containing antibiotics was placed inside the wound. Gentamicin therapy was started at a dose of $5 \mathrm{mg} / \mathrm{kg}$ and Ketoprofen at $3 \mathrm{mg} / \mathrm{kg}$. The pig partially recovered food consumption and movements but had very poor physical condition; it was sacrificed with Euthanex ${ }^{\circledR}$ (Invet, Bogotá, Colombia) intravenously, followed by necropsy examination.

\section{Diagnostic aids}

Microbiological culture and an automatic biochemical identification test (Table 1) using BD PhoenixTM PMIC/ID panels (Becton Dickinson, Sparks, MD, USA) was conducted for the first sample of pus and identified $T$. pyogenes, with $99 \%$ confidence level as the

Cuadro 1. Características bioquímicas de Trueperella (Arcanobacterium) pyogenes aisladas de abscesos de cerdo obtenidas con el uso de paneles PMIC/Identificación BD Phoenix ${ }^{\mathrm{TM}}$.

Table 1. Biochemical features of Trueperella (Arcanobacterium) pyogenes isolated from pig's abscesses and using BD Phoenix TM PMIC/ID panels

\begin{tabular}{|c|c|c|c|c|c|c|c|c|}
\hline Biochemical test & Code & Result & Biochemical test & Code & Result & Biochemical test & Code & Result \\
\hline ARGININE-ARGININE-AMC & A_ARARR & - & GLYCINE-PROLINE-AMC & A_GLPRB & - & L-ALANINE-AMC & A_LALT & - \\
\hline L-ARGININE-AMC & A_LARGH & - & L-HISTIDINE-AMC & A_LHIST & - & L-ISOLEUCINE-AMC & A_LISO & - \\
\hline L-LUECINE-AMC & A_LLEUH & + & L-PHENYLALANINE-AMC & A_LPHET & - & L-PROLINE-AMCA_LPROB & A_LPROB & + \\
\hline L-PYROGLUTAMIC ACID-AMC & A_LPYR & + & L-TRYPTOPHAN-AMC A_LTRY & A_LTRY & - & METHIONINE-AMC & A_META & - \\
\hline 3-METHYL GLUTARIC ACID & C_3MGA & + & COLISTINC_CLST & C_CLST & - & D-FRUCTOSE & C_DFRU & - \\
\hline D-GLUCONIC ACID & C_DGUA & + & D-MANNITOL C_DMNT & C_DMNT & - & IMINODIACETIC ACID & C_IMN & + \\
\hline ALPHA-KETOGLUTARIC ACID & C_KGA & + & 3-METHYLADIPIC ACID & C_MAA & + & POLYMYXIN B & C_PxB & - \\
\hline THYMIDINE & C_THY & + & 4MU-AD-GLUCOSIDE & M_ADGLU & - & 4MU-BD-CELLOBIOSIDE & M_BDCEL & \\
\hline 4MU-BD-GALACTOSIDE & M_BDGAL & + & 4MU-BD-GLUCURONIDE & M_BDGLC & - & 4MU-BD-GLUCOSIDE & M_BDGLU & - \\
\hline 4MU-N-ACETYL-BD-GLUCOS AMINIDE & M_NAG & - & 4MU-PHOSPHATE & M_PHOS & - & 4MU-PHOSPHATE (with Trenalose) & M_PHOT & - \\
\hline ALANINE-ALANINE-PNA N_ALALH & N_ALALH & - & L-PROLINE-PNA & N_LPROT & - & VALINE-ALANINE-PNA & N_VAALA & - \\
\hline PNP-AD-GLUCOSIDE & P_ADGLU & - & PNP-PHOSPHATE & P_PHOL & - & BETA-GENTIOBIOSE & R_BGEN & - \\
\hline DEXTROSE & R_DEX & - & D-SUCROSE & R_DSUC & - & D-TAGATOSE & R_DTAG & - \\
\hline D-THEHALOSE & R_DTRE & - & MALTOSE & R_MAL & - & D_GLUCOPYRANOSIDE & R_MGP & - \\
\hline MALTOTRIOSE & R_MTT & - & N-ACETYL-GLUCOSAMINE & R_NGU & - & UREA & S_URE & - \\
\hline ESCULIN & T_ESC & & & & & & & \\
\hline
\end{tabular}

NOTE: $(-)=$ Negative, $(+)=$ Positive. 


\section{Ayudas diagnósticas}

Cultivo microbiológico y una prueba de identificación bioquímica automática (Tabla 1) a través del uso de paneles BD Phoenix ${ }^{T M}$ PMIC/ ID (Becton Dickinson, Sparks, MD, USA) se llevó a cabo para la primera muestra de pus y se identificó a T. pyognes como el único microorganismo presente en la muestra con un $99 \%$ de nivel de confianza, excluyendo la posibilidad de una infección mixta. Las pruebas de sensibilidad a antimicrobianos con sensidiscos siguiendo el método de Kirby Bauer y las categorías establecidas por el Instituto de Estándares Clínicos y de Laboratorio(15), indicó que $T$. pyogenes fue sensible a gentamicina, ampicilina, ampicilina sulbactam, amoxicilinaclavulánico y trimetoprima-sulfa, mientras que fue resistente a la penicilina y oxacilina. $T$. pyogenes también se aisló en cultivo puro de la segunda muestra de pus, no obstante en este caso no se realizaron las pruebas de susceptibilidad a antimicrobianos.

En la necropsia, el hígado, el bazo, el riñón, el pulmón y el tracto gastrointestinal no tenían lesiones aparentes. Por el contrario, los abscesos se limitaron al pliegue cutáneo del cuello, la articulación tarsal de la extremidad posterior derecha y el tejido muscular subyacente (Figura 2). Una sección transversal por encima de la articulación tarsal mostró hemorragias en la piel y el músculo que rodea la tibia y el hueso peroné (Figura 2B). El nodo linfático poplíteo de la extremidad afectada estaba ligeramente inflamado en comparación con el nodo linfático ipsilateral. El examen histopatológico de una sección de piel mostró una reacción inflamatoria severa en la dermis y la hipodermis con microabscesos en diferentes etapas de desarrollo (Figura 2C). Una gran cavidad de un absceso drenado contenía abundantes células necróticas e inflamatorias (Figura 2D) asociadas con bacterias pleomórficas.

T. pyogenes es un habitante normal de la piel y mucosas, que sirven como fuente autógena de infecciones oportunistas en una variedad de hospederos animales, con particular severidad only microorganism present in the sample and excluding a mixed infection. Antimicrobial susceptibility testing was conducted by using BD PhoenixTM PMIC/ID panels and the categories established by The Clinical and Laboratory Standards Institute(16), indicated that T. pyogenes was sensitive to Gentamicin, Ampicillin, Sulbactam Ampicillin, Amoxicillin clavulanate and Trimethoprim sulfa, whereas it was resistant to Penicillin and Oxacillin. $T$. pyogenes was also isolated in pure culture from the second sample of pus but at this time, no antimicrobial susceptibility tests were performed.

At necropsy, the liver, spleen, kidney, lung and the gastrointestinal tract had no apparent lesions. By contrast, abscesses were limited to

Figura 2. Características anatomo-patológicas y microscópicas de los abscesos cutáneos causados por T. pyogenes en un cerdo Duroc-Jersey

Figure 2. Anatomo-pathological and microscopic features of cutaneous abscesses caused by $T$. pyogenes in a Duroc-Jersey pig

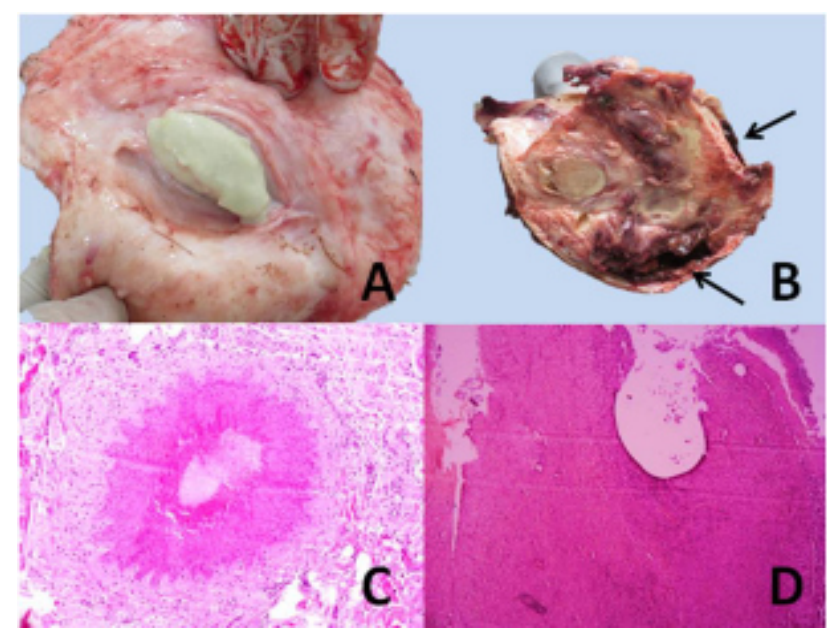

A) Emerging pus of an abscess removed from the neck skinfold. B) Cross-section above the tarsal joint exposing the hemorrhagic cavities with necrotic appearance (Arrows). C) Histological features of a small pyogranuloma on the dermis, note the thick capsule formed by epithelioid cells followed by another layer of inflammatory cells and a necrotic core. D) Severe inflammatory reaction surrounding the abscess's cavity. The inflammatory cells corresponded to abundant neutrophils and macrophages surrounded by fibroblasts. 
en cerdos y el ganado. Las inyecciones subcutáneas sin desinfección adecuada del lugar de la inyección y el uso de la misma jeringa y la aguja en diferentes animales pueden ser otra fuente de infección(11), así como la transmisión horizontal durante mordeduras esporádicas entre animales. La ubicación del absceso en el pliegue cutáneo del cerdo en este estudio (Figura 1) excluyeron la posibilidad de ser adquirida por inyección subcutánea. En cambio, el origen más probable de los abscesos serían mordeduras esporádicas procedentes de cerdas durante la monta o heridas en la piel inducidas durante la manipulación.

T. pyogenes causa abscesos hepáticos, mastitis y metritis en bovinos y neumonía y artritis en el ganado porcino(1). Infecciones bacterianas o virales previas pueden predisponer a la enfermedad grave en cerdos(17). A pesar de la artritis supurativa severa localizada en la articulación del tarso, los ganglios linfáticos cutáneos de la extremidad no se inflamaron consistentemente y sólo el ganglio linfático poplíteo fue moderadamente edematoso y ligeramente hemorrágico. La ausencia de lesiones en órganos internos sugiere que la infección se localizó en la articulación y tejidos circundantes, y la inflamación limitó la propagación de la bacteria al compartimento sistémico. Sin embargo, no se intentó aislamiento bacteriano a partir del ganglio linfático poplíteo o el bazo y $T$. pyogenes ha sido aislada de los ganglios linfáticos de cerdos al sacrificio con o sin linfadenitis(18). Por lo tanto, T. pyogenes puede colonizar tejidos profundos sin inflamación concomitante, un proceso que parece ser facilitado por la producción de exotoxinas tales como pyolysin y proteasas $(1,19)$.

T. pyogenes posee un amplio perfil de resistencia a antimicrobianos $(9,20)$. Sin embargo, los aislados en este estudio fueron susceptibles a diversos antimicrobianos incluyendo gentamicina, ampicilina, ampicilina-sulbactam, amoxicilina-ácido clavulánico y trimetoprim-sulfa, similar a la sensibilidad reportada para $T$. pyogenes aislada a partir de mastitis clínica(21), sin embargo, los the skin fold of the neck, the tarsal joint of the right hind limb and underlying muscle tissue (Figure 2). A cross-section above the tarsal joint showed hemorrhagic skin and muscle surrounding the tibia and peronei bones (Figure 2B). The popliteal lymph node of the affected limb was slightly swollen when compared to the ipsilateral lymph node. Histopathological examination of a skin section showed severe inflammatory reaction in the dermis and hypodermis with micro-abscesses at different stages of development (Figure 2C). A large cavity of a drained abscess contained abundant necrotic and inflammatory cells (Figure 2D) associated with pleomorphic bacteria.

T. pyogenes is a normal inhabitant of the skin and mucosal tissues which serve as autogenous source for opportunistic infections in a variety of animal hosts, with particular severity in pigs and cattle. Subcutaneous injections without proper disinfection of the injection site and by using the same syringe and needle in different animals may be another source of infection(11), as well as horizontal transmission during sporadic bites between animals. The locations of the abscesses in the pig of this study (Figure 1) excluded the possibility to be acquired by subcutaneous injection. Instead, the most probably origin of the abscesses would be sporadic bites from sows during mounting or skin wounds during handling.

T. pyogenes causes liver abscesses, mastitis and metritis in cattle and pneumonia and arthritis in swine(1). Previous bacterial or viral exposure may predispose to severe disease in swine(17). Despite the severe suppurative arthritis located at the tarsal joint, the cutaneous lymph nodes of the limb were no consistently inflamed and only the popliteal lymph node was moderately edematous and slightly hemorrhagic. Absence of lesions in internal organs suggests that the infection was localized to the joint and surrounding tissues and the inflammation limited the spread of the bacterium to the systemic compartment. However, bacterial isolation was not conducted from the popliteal lymph node 
tratamientos con antibióticos seleccionados no fueron eficaces en el tratamiento de la infección. La razón más probable para este hallazgo puede ser una baja concentración de antibiótico capaz de atravesar la capsula y llegar al centro del piogranuloma.

En Colombia, T. pyogenes se asoció inicialmente con baja frecuencia de las descargas vulvares en cerdas(22), y más recientemente con mastitis(23) y trastornos reproductivos en el ganado(24). Los abscesos en el cerdo aquí presentados se caracterizan por una pared gruesa formada por células epiteliales y fibroblastos y un núcleo necrótico eosinofílico, que son consistentes con las descripciones anteriores(12).

T. pyogenes fue aislado de abscesos cutáneos que comprometieron la capacidad reproductiva y la esperanza de vida de un cerdo macho. A pesar de la susceptibilidad a diversos antimicrobianos, los tratamientos establecidos y el drenaje quirúrgico del absceso no lograron controlar la infección. Este es el primer reporte de $T$. pyogenes causante de abscesos cutáneos graves en cerdos en Colombia que progresaron a artritis supurativa. Datos epidemiológicos indican la posibilidad de la presencia de nuevos casos en la misma granja, lo cual revela la necesidad de establecer una vigilancia apropiada y métodos de diagnóstico rápido como la reacción en cadena de la polimerasa (PCR) para la detección temprana de la infección. El aislamiento y cuarentena de animales que desarrollan abscesos, una desinfección vigorosa de materiales, instrumentos quirúrgicos y facilidades animales y un entrenamiento apropiado de los operarios en medidas de bioseguridad, podrían ser requeridas para prevenir o controlar la infección por este patógeno oportunista.

\section{AGRADECIMIENTOS}

Agracemos a la Facultad de Medicina Veterinaria y Zootecnia de la Universidad del Tolima por el apoyo financiero. or spleen and T. pyogenes has been isolated from lymph nodes of slaughtered swine with or without lymphadenitis(18). Thus, T. pyogenes may colonize deep tissues without concomitant inflammation, a process that seems to be facilitated by production of exotoxins such as pyolysin and proteases $(1,19)$.

A broad antimicrobial resistance profile had been reported in $T$. pyogenes $(9,20)$. However, the isolates in this study were susceptible to various antimicrobials including Gentamicin, Ampicillin, Sulbactam Ampicillin, Amoxicillin clavulanate and Trimethoprim Sulfa, similar to those reported in T. pyogenes isolated from clinical mastitis(21), nevertheless, the selected antibiotic treatments appeared to be non-efficacious to treat the infection. The most probably reason for these findings may be a low concentration of antibiotic reaching the pyogranuloma core.

In Colombia, T. pyogenes was initially associated with low frequency of vulvar discharges in sows (22), and most recently with mastitis(23) and reproductive disorders in cattle(24). The abscesses in pigs reported here were characterized by a thick wall formed by epithelioid cells and fibroblasts and an eosinophilic necrotic core, which are consistent with previous descriptions(12).

T. pyogenes was isolated from cutaneous abscesses that compromised the reproductive ability and life expectancy of a male pig. Despite the susceptibility to various antimicrobials, the established treatments and the surgical drainage of the abscess failed to control the infection. To our knowledge, this is the first report of $T$. pyogenes causing severe cutaneous abscesses in pigs that progressed into suppurative arthritis in Colombia. Epidemiological data indicates that additional cases might be present in the same farm and reveals the need to establish proper surveillance and rapid diagnostic methods, including polymerase chain reaction (PCR) for early detection of the infection. Isolation and quarantine of animals developing abscesses, vigorous disinfection of materials, surgical 


\section{LITERATURA CITADA}

1. Jost $\mathrm{BH}$, Billington SJ. Arcanobacterium pyogenes: molecular pathogenesis of an animal opportunist. Antonie Van Leeuwenhoek 2005;88:87-102.

2. Reddy C, Cornell C, Fraga A. Transfer of Corynebacterium pyogenes (Glage) Eberson to the Genus Actinomyces as Actinomyces pyogenes (Glage) comb. Nov. Int J Syst Bacteriol 1982;32:419-429.

3. Ramos CP, Foster G and Collins MD. Phylogenetic Analysis of the Genus Actinornyces Based on 16s rRNA Gene Sequences: Description of Arcanobacteriurn phocae sp. nov., Arcanobacterium bernardiae comb. nov., and Arcanobacterium pyogenes comb. nov. Int J Syst Bacteriol 1997;47:46-53.

4. Yassin AF, Hupfer $H$, Siering $C$, Schumann P. Comparative chemotaxonomic and phylogenetic studies on the genus Arcanobacterium Collins et al. 1982 emend. Lehnen et al. 2006: proposal for Trueperella gen. nov. and emended description of the genus Arcanobacterium. Int J Syst Evol Microbiol 2011;61:1265-1274.

5. Jost BH, Post KW, Songer JG, Billington SJ. Isolation of Arcanobacterium pyogenes from the porcine gastric mucosa. Vet Res Commun 2002;26:419-425.

6. Clerc K, Cordero F, Saldivia C, Vásquez L, García M. Facial abscesses produced by Actinomyces pyogenes (Arcanobacterium pyogenes) in a Senepol bull. Rev Fac Cs Vets $2004 ; 45: 1-8$.

7. Narayanan S, Nagaraja TG, Staats J, Chengappa MM, Oberst RD. Biochemical and biological characterizations and ribotyping of Actinomyces pyogenes and Actinomyces pyogenes-like organisms from liver abscesses in cattle. Vet Microbiol 1998;61:289-303.

8. Ertas H, Kilik A, Ozbey G, Muz A. Isolation of Arcanobacterium (Actinomyces) pyogenes from abscessed cattle kidney and identification by PCR. Turk J Vet Anim Sci 2005;29:455-459.

9. Malinowski $\mathrm{E}$, Lassa $\mathrm{H}$, Markiewicz $\mathrm{H}$, Kaptur M, Nadolny M, Niewitecki W, et al. Sensitivity to antibiotics of Arcanobacterium pyogenes and Escherichia coli from the uteri of cows with metritis/endometritis. Vet J 2011;187:234238.

10. Kalmus $\mathrm{P}$, Simojoki H, Pyorala S, Taponen S, Holopainen J, Orro T. Milk haptoglobin, milk amyloid $\mathrm{A}$, and $\mathrm{N}$-acetylbeta-D-glucosaminidase activity in bovines with naturally occurring clinical mastitis diagnosed with a quantitative PCR test. J Dairy Sci 2013;96:3662-3670.

11. Gerlach BM, Houser TA, Hollis LC, Tokach MD, Nietfeld JC, Higgins JJ, et al. Incidence and severity of Arcanobacterium pyogenes injection site abscesses with needle or needlefree injection. Meat Sci 2012;92:805-807.

12. Martinez J, Jaro PJ, Aduriz G, Gomez EA, Peris B, Corpa JM. Carcass condemnation causes of growth retarded pigs at slaughter. Vet J 2007;174:160-164.

13. Cannon J, Morgan J, MCKeith F, Smith G, Sonka S, Heavner $J$, et al. Pork chain quality audit survey: quantification of pork quality characteristics. J Muscle Foods 1996;7:29-44.

14. Kavitha K, Latha R, Udayashankar C, Jayanthi K, Oudeacoumar P. Three cases of Arcanobacterium pyogenesassociated soft tissue infection. J Med Microbiol 2010;59:736739. instruments, and animal facilities, and appropriate training of personal on farm's biosecurity measures might also be required to prevent or control the infection by this opportunistic pathogen.

\section{ACKNOWLEDGMENTS}

We thank to the Faculty of Veterinary Medicine, The University of Tolima for financial support.

End of english version

15. Levy CE, Pedro RJ, Von Nowakonski A, Holanda LM, Brocchi M, Ramo MC. Arcanobacterium pyogenes sepsis in farmer, Brazil. Emerg Infect Dis 2009;15:1131-1132.

16. CLSI. Performance Standards for Antimicrobial Disk Susceptibility Tests; Approved Standard-Ninth Edition 2006. M2A9 Vol. 26. No. 1.

17. Karniychuk UU, Geldhof M, Vanhee M, Van Doorsselaere J, Saveleva TA, Nauwynck HJ. Pathogenesis and antigenic characterization of a new East European subtype 3 porcine reproductive and respiratory syndrome virus isolate. BMC Vet Res 2010;6:30.

18. Lara GH, Ribeiro MG, Leite CQ, Paes AC, Guazzelli A, da Silva AV, et al. Occurrence of Mycobacterium spp. and other pathogens in lymph nodes of slaughtered swine and wild boars (Sus scrofa). Res Vet Sci 2011;90:185-188.

19. Jost BH, Songer JG, Billington SJ. An Arcanobacterium (Actinomyces) pyogenes mutant deficient in production of the pore-forming cytolysin pyolysin has reduced virulence. Infect Immun 1999;67:1723-1728.

20. Zhao KL, Liu $Y$, Zhang $X Y$, Palahati $P$, Wang HN, Yue BS. Detection and characterization of antibiotic-resistance genes in Arcanobacterium pyogenes strains from abscesses of forest musk deer. J Med Microbiol 2011;60:1820-1826.

21. Zastempowska E, Lassa H. Genotypic characterization and evaluation of an antibiotic resistance of Trueperella pyogenes (Arcanobacterium pyogenes) isolated from milk of dairy cows with clinical mastitis. Vet Microbiol 2012;161:153158.

22. CORPOICA. Corporación Colombiana de Investigación Agropecuaria. Productos y Procesos tecnológicos por macroregión. Santafé de Bogotá. 1998.

23. Calderón A, Rodríguez V. Prevalencia de mastitis bovina y su etiologia infecciosa en sistemas especializados en produccion de leche en el altiplano cundiboyacense (Colombia). Rev Colomb Cienc Pecu 2008;21:582-589.

24. Sánchez $M$, González $C$, Castañeda R, Pulido $A$, Guáqueta $\mathrm{H}$, Aranda $\mathrm{M}$, et al. Evaluación citológica y microbiológica de lavados uterinos en bovinos con problemas reproductivos (estudio preliminar). Rev MVZ Cordoba 2011;16:2711-2720. 